\author{
Bogustaw Luchter \\ Katedra Gospodarki Regionalnej \\ Uniwersytet Ekonomiczny w Krakowie
}

\title{
Przemiany użytkowania ziemi w centralnej części Krakowa - byłej dzielnicy katastralnej Śródmieście w latach 1992-2012
}

\section{Streszczenie}

Celem artykułu jest ocena przemian użytkowania ziemi zachodzących pod wpływem procesów wynikających z rozpoczęcia wdrażania zasad gospodarki rynkowej w ostatnich latach, tj. 1992-2012, w centralnej części Krakowa - tj. w Sródmieściu. Badania zostały przeprowadzone zarówno na terenie całej dzielnicy, jak i w obrębie wchodzących w jej skład bloków urbanistycznych.

Analizę przeprowadzono, opierając się na kategoriach użytków (w podziale pierwszego stopnia szczegółowości podziału użytków), grupach (w podziale drugiego stopnia) i formach użytkowania ziemi (w podziale trzeciego stopnia).

Badania wykazały wzrost procesów metropolitalnych, przejawiających się wzrostem powierzchni terenów usługowych, zwłaszcza o zasięgu międzynarodowym: kultury, nauki i turystyki. Te trzy dziedziny stanowią od wielu lat główne funkcje rozwoju przestrzennego i społeczno-gospodarczego miasta Krakowa.

Słowa kluczowe: geografia ekonomiczna, geografia osadnictwa, gospodarka przestrzenna, użytkowanie ziemi przestrzeni miejskiej. 


\section{Wprowadzenie}

Zachodzące w Polsce po 1989 r. przemiany, wiążące się z przejściem z centralnie sterowanej gospodarki socjalistycznej do gospodarki rynkowej, uwidoczniły się także w przeobrażeniach struktury użytkowania ziemi. Można je było zaobserwować zwłaszcza w miastach, szczególnie w ich centralnych częściach.

Ekstensywnie użytkowane tereny (np. przez przemysł) na skutek przywrócenia mechanizmu renty gruntowej, w tym ceny ziemi, zmieniły istotnie swój charakter.

Przystąpienie Polski do Unii Europejskiej w 2004 r. spowodowało wzrost znaczenia funkcji charakterystycznych dla miast odznaczających się najwyżej rozwiniętymi procesami urbanizacyjnymi. To przyczyniło się do rozwoju funkcji metropolitalnych, które wpłynęły na strukturę przestrzenną największych miast w Polsce (Warszawa, Łódź, Wrocław, Poznań, Gdańsk, Kraków). Przekształcenia te uwidoczniły się także w strukturze użytkowania ziemi - przestrzeni miejskiej ${ }^{1}$, szczególnie centralnych części tego typu jednostek osadniczych.

Celem niniejszego artykułu jest ocena przemian użytkowania ziemi zachodzących pod wpływem procesów związanych z wdrażaniem zasad gospodarki rynkowej w ostatnich 20 latach (1992-2012) na przykładzie centralnej części Krakowa, prowadzących do rozwoju procesów metropolitalnych, polegających na wzroście znaczenia funkcji wyższego rzędu wobec funkcji podstawowych, charakterystycznych dla jednostek osadniczych o zasięgu lokalnym lub intraregionalnym.

\section{Zarys procedury badawczej}

Badania przeprowadzono na przykładzie Śródmieścia, najstarszej obok Wawelu jednostki katastralnej ${ }^{2}$, wchodzącej w skład współczesnego Krakowa ${ }^{3}$, zajmującej 79 ha, tj. ok. 0,24\% ogółu powierzchni współczesnego miasta.

\footnotetext{
${ }^{1}$ Pojęcie użytkowanie ziemi przestrzeni miejskiej wprowadzili do literatury K. Bromek i R. Mydel [1972].

${ }^{2}$ Nazwa pochodzi od katastru galicyjskiego opracowanego w zaborze austriackim w poł. XIX w., kiedy to dla potrzeb ewidencji gruntów wprowadzono podstawowe jednostki przestrzenne - tzw. gminy katastralne, którymi były dawne wsie i małe miasta. Dla dużych miast wprowadzono podział na dzielnice katastralne. Przykładowo Kraków w latach 1867-1951 dzielił się początkowo (1867-1910) na osiem, a ostatecznie (tuż przed reorganizacją podziału administracyjnego miasta w 1951 r.) na 64 dzielnice katastralne. Przez jednostki katastralne rozumiane są dawne gminy katastralne (wsie) przyłączone do Krakowa po 1951 r. oraz dzielnice katastralne, funkcjonujące do $1951 \mathrm{r}$.

${ }^{3}$ Dnia 1.01.2013 r. nieznacznie, tj. o ponad 4 ha, powiększono terytorium miasta Krakowa o skrawek Zastowa (wsi położonej w powiecie krakowskim, należącej do gminy Kocmyrzów-Luborzyca) [Kraków... 2013, s. 80].
} 
Śródmieście wraz z Wawelem stanowiło Kraków w granicach sprzed $1791 \mathrm{r}$. [Górka 2004, s. 22]. Ukształtowane zostało pod względem urbanistycznym już wcześniej, co potwierdziły badania Z. Górki [1974, 2004] czy autora niniejszego artykułu [Luchter 1987a, 1994, 1997]. Odznaczało się ono w ostatnich latach przede wszystkim zmianami jakościowymi, będącymi następstwem wdrażania zasad gospodarki rynkowej.

W badaniach uwzględnione zostały formy użytkowania ziemi przyjęte w rozprawie doktorskiej autora [Luchter 1987a], na podstawie założeń metodycznych opracowanych przez K. Bromka i R. Mydela [1972]. Z biegiem czasu uległy one modyfikacji, głównie wskutek przemian polityczno-gospodarczych zachodzących po 1990 r. w Polsce, a także postępu technicznego w budownictwie na świecie.

Dla Śródmieścia wyróżniono trzy kategorie użytkowania ziemi (w podziale pierwszego stopnia szczegółowości podziału użytków): tereny zielone, użytki techniczne i nieużytki. Pozostałe kategorie (tereny specjalne, wody, pozostałe użytki) na terenie Śródmieścia nie występowały.

W obrębie tych kategorii wyodrębniono osiem grup użytków (zgodnie z drugim stopniem szczegółowości podziału użytków) oraz 34 (w 2012 r.) bądź 35 (w 1992 r.) form użytkowania ziemi (w podziale trzeciego stopnia szczegółowości użytków) ${ }^{4}$.

Przyjęcie różnego stopnia szczegółowości użytków umożliwiło wysunięcie zarówno ogólnych, jak i szczegółowych, czy nawet bardzo szczegółowych wniosków.

Podstawową skalą badań była skala 1 : 10 000, odpowiadająca w 1992 r. załącznikom kartograficznym miejscowego planu ogólnego zagospodarowania przestrzennego, a współcześnie (tj. w 2014 r.) - studium uwarunkowań i kierunków zagospodarowania przestrzennego.

Do oceny stopnia przemian użytkowania ziemi wykorzystano sumaryczne wartości dodatnich bądź ujemnych odchyleń zmienności udziału procentowego powierzchni poszczególnych użytków w powierzchni ogólnej $\left(z_{i}\right)$, zgodnie z następującymi założeniami:

$$
\begin{array}{ll}
z_{i}^{+}=\sum_{j=1}^{m}\left(W_{i j}^{(2)}-W_{i j}^{(1)}\right), & \operatorname{gdy} W_{i j}^{(2)}>W_{i j}^{(1)} \\
z_{i}^{-}=\sum_{j=1}^{m}\left(W_{i j}^{(2)}-W_{i j}^{(1)}\right), & \operatorname{gdy} W_{i j}^{(2)}<W_{i j}^{(1)},
\end{array}
$$

przy czym:

$z_{i}^{+}$- wartość sumaryczna zmienności dodatnich odchyleń procentowego udziału poszczególnych kategorii, grup lub form użytkowania ziemi, wyliczona dla określonej jednostki przestrzennej $i$ (w tym przypadku Śródmieścia), wyrażona w punktach procentowych;

${ }^{4}$ Przykładowo w pracy doktorskiej autor niniejszego artykułu przyjął 106 form użytkowania ziemi, 16 grup użytków i sześć kategorii użytków [Luchter 1987a]. 
$z_{i}^{-}$- wartość sumaryczna zmienności ujemnych odchyleń procentowego udziału poszczególnych kategorii, grup lub form użytkowania ziemi, wyliczona dla określonej jednostki przestrzennej $i$, wyrażona w punktach procentowych;

$W_{i j}^{(1)}$ - wskaźnik procentowego udziału powierzchni użytku $j$ w powierzchni określonej jednostki przestrzennej $i$ w okresie $t_{1}$ (wcześniejszym, w tym przypadku w 1992 r.), wyliczony zgodnie ze wzorem:

$$
W_{i j}^{(1)}=\frac{x_{i j}^{(1)}}{\sum_{j=1}^{m} x_{i j}^{(2)}} \cdot 100(\%),
$$

gdzie:

$x_{i j}^{(1)}$ - powierzchnia tego samego użytku $j$ w obrębie tej samej jednostki przestrzennej $i$ w okresie $t_{l}$;

$W_{i j}^{(2)}$ - wskaźnik procentowego udziału powierzchni tego samego użytku $j$ w powierzchni ogólnej tej samej jednostki przestrzennej $i$ w okresie $t_{2}$ (późniejszym, w tym przypadku w 2012 r.), wyliczony analogicznie:

$$
W_{i j}^{(2)}=\frac{x_{i j}^{(2)}}{\sum_{j=1}^{m} x_{i j}^{(2)}} \cdot 100(\%),
$$

przy czym:

$x_{i j}^{(2)}$ - powierzchnia tego samego użytku $j$ w obrębie tej samej jednostki przestrzennej $i$ w okresie $t_{2}$.

Zgodnie z wyliczeniami:

$$
\begin{gathered}
-100 \leq z_{i}^{-} \leq 0 \quad \mathrm{i} \quad 100 \geq z_{i}^{+} \geq 0 \\
\left|z_{i}^{+}\right|=\left|z_{i}^{-}\right|, \quad \text { stąd } \quad 0 \leq\left|z_{i}^{(+)(-)}\right| \leq 100
\end{gathered}
$$

$z_{i}=z_{i}^{+}+z_{i}^{-}=0$, ponieważ:

$$
\sum_{j=1}^{m}\left(W_{i j}^{(2)}-W_{i j}^{(1)}\right)=0, z_{i}=0 \text {, także gdy } W_{i j}^{(1)}=W_{i j}^{(2)} .
$$

Wartości te uzyskano w wyniku sumowania odchyleń dodatnich bądź ujemnych.

Suma odchyleń dodatnich $z_{i}^{+}$równa jest sumie $z_{i}^{-}$odchyleń ujemnych. Wartość ujemna wystąpiła wówczas, gdy udział tej samej kategorii (grupy bądź formy użytkowania ziemi) w powierzchni ogólnej danej jednostki przestrzennej był mniejszy dla okresu późniejszego $\left(t_{2}\right)$ niż analogicznie wyliczony dla okresu wcześniejszego $\left(t_{1}\right)$. Odwrotnie, wartość dodatnia wystąpiła wtedy, gdy procentowy udział danej 
kategorii, grupy, formy) użytkowania ziemi był większy dla okresu późniejszego $\left(t_{2}\right)$ niż dla okresu wcześniejszego $\left(t_{1}\right)^{5}$.

Wartość $0 \leq\left|z_{i}\right| \leq 100$. Może ona wynieść $0 \mathrm{w}$ przypadku terenów, w obrębie których nie zaobserwowano żadnych zmian, ekstremalnie natomiast może osiągnąc 100 . Dotyczy to dla odmiany obszarów, gdzie doszło do całkowitych zmian użytkowania ziemi.

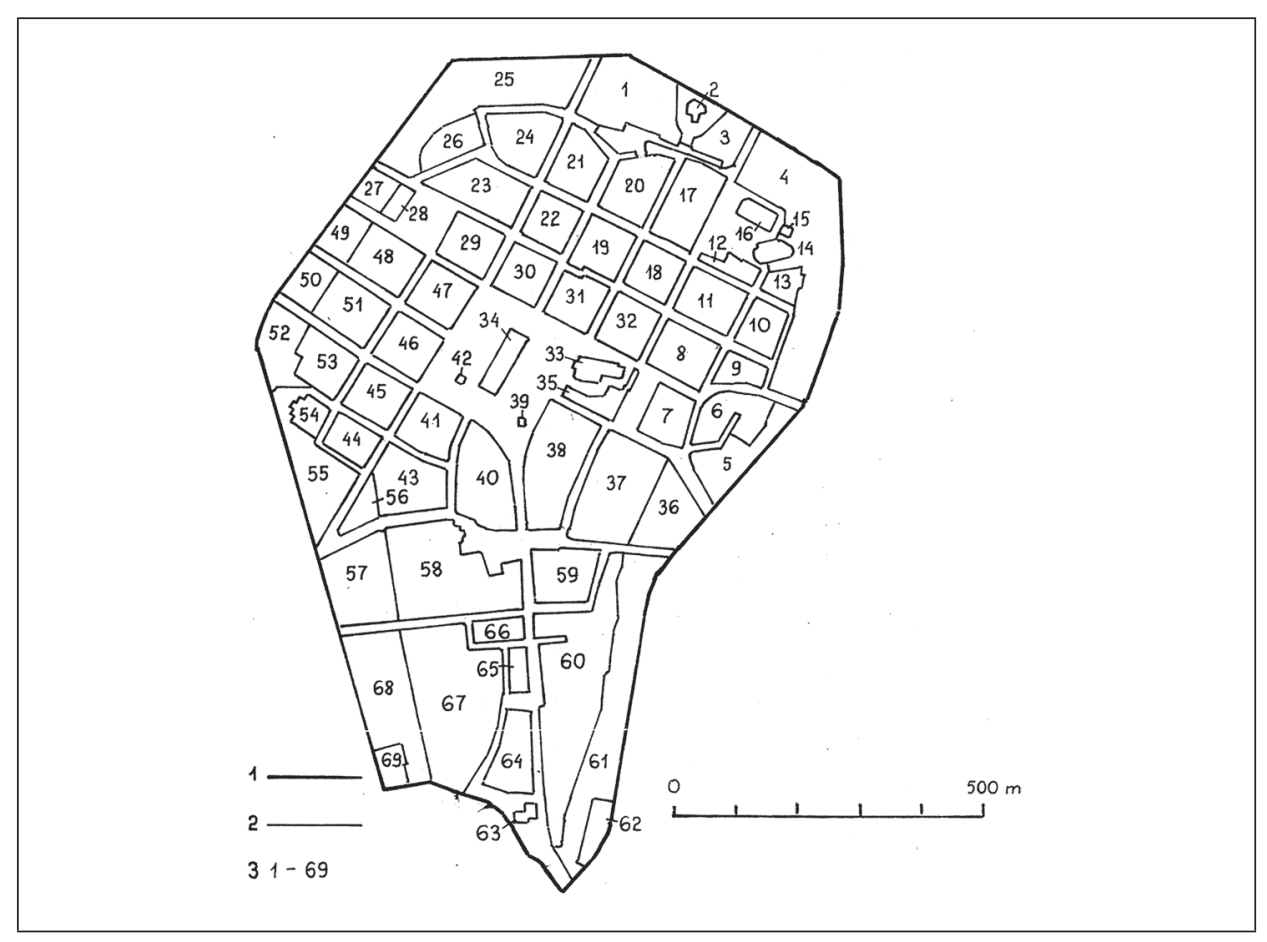

Objaśnienia: 1 - granice dzielnicy, 2 - granice bloków urbanistycznych, 3 - numery bloków urbanistycznych.

Rys. 1. Była I dzielnica katastralna miasta Krakowa - Śródmieście w podziale na bloki urbanistyczne

Źródło: opracowanie własne na podstawie [Luchter 1994, s. 185].

W przypadku ukształtowanego historycznie Śródmieścia Krakowa zmiany 100-procentowe $\left(\left|z_{i}\right|=100\right)$ nie są już możliwe, z racji zachowania podstawowej tkanki urbanistycznej, do jakiej zaliczyć można np. Rynek Główny, układ i przebieg ulic itp. Całkowite przeobrażenia zaobserwować można jedynie w obrębie

${ }^{5}$ Szczegółowe zasady konstrukcji wartości $z_{i}$ omówione zostały w pracy habilitacyjnej autora [Luchter 2010, s. 81-82]. 
jednostek przestrzennych, wyróżnionych pod względem podobieństwa cech funkcjonalnych (obręby ewidencyjne, jednostki urbanistyczne), technicznych (bloki urbanistyczne, działki ewidencyjne), bądź też przyjętych pomocniczo dla celów badawczych (np. kwadraty).

Badania przeprowadzone zostały zarówno dla całej jednostki katastralnej - tj. byłej I dzielnicy katastralnej miasta Krakowa - Śródmieścia, jak i ukształtowanych pod względem genetycznym 69 bloków urbanistycznych, wchodzących w jej skład (rys. 1) ${ }^{6}$.

W analizie porównawczej wykorzystany został przedział czasowy 1992-2012, obejmujący początkowe etapy wdrażania zasad gospodarki rynkowej. Dobór lat 1992 i 2012 wynikał również z dostępu do danych empirycznych, pochodzących z badań terenowych autora, przeprowadzonych na terenie Śródmieścia w lipcuwrześniu 1992 r. i dla celów porównawczych w tych samych miesiącach - 2012 r. Rezultaty badań pochodzące z 1992 r. zawarte zostały w jednej z publikacji autora [Luchter 1994, tab. 1].

Tabela 1. Zmiany użytkowania ziemi na terenie byłej I dzielnicy katastralnej miasta Krakowa - Śródmieście w latach 1992-2012

\begin{tabular}{|c|c|c|c|c|c|c|c|c|c|}
\hline \multirow{3}{*}{ Lp. } & \multirow{3}{*}{ Użytki } & \multicolumn{2}{|c|}{$\begin{array}{c}\text { Odsetek powierzchni } \\
\text { ogólnej w \% w roku }\end{array}$} & \multicolumn{6}{|c|}{$\begin{array}{l}\text { Zmiany udziału w punktach } \\
\text { procentowych według }\end{array}$} \\
\hline & & \multirow[t]{2}{*}{1992} & \multirow[t]{2}{*}{2012} & \multicolumn{2}{|c|}{$\begin{array}{l}\text { kategorii } \\
\text { użytków }\end{array}$} & \multicolumn{2}{|c|}{$\begin{array}{l}\text { grup } \\
\text { użytków }\end{array}$} & \multicolumn{2}{|c|}{$\begin{array}{c}\text { form } \\
\text { użytkowania } \\
\text { ziemic }^{c}\end{array}$} \\
\hline & & & & \begin{tabular}{|l} 
do- \\
datnie
\end{tabular} & $\begin{array}{l}\text { ujem- } \\
\text { ne }\end{array}$ & $\begin{array}{c}\text { do- } \\
\text { datnie }\end{array}$ & $\begin{array}{l}\text { ujem- } \\
\text { ne }\end{array}$ & $\begin{array}{c}\text { do- } \\
\text { datnie }\end{array}$ & $\begin{array}{l}\text { ujem- } \\
\text { ne }\end{array}$ \\
\hline I & $\begin{array}{l}\text { Tereny zielone } \\
\text { 1. Pozostałe tereny zielone: } \\
\text { a) ogrody historyczne } \\
\text { b) parki } \\
\text { c) skwery } \\
\text { d) zieleńce }\end{array}$ & $\begin{array}{c}27,2 \\
27,2 \\
2,3 \\
23,6 \\
0,99 \\
0,31\end{array}$ & $\begin{array}{c}27,27 \\
27,27 \\
2,3 \\
23,89 \\
1,08 \\
\end{array}$ & $\begin{array}{c}+0,07 \\
\cdot \\
\cdot \\
\cdot \\
\cdot \\
\cdot\end{array}$ & $\begin{array}{l}\cdot \\
. \\
. \\
. \\
.\end{array}$ & $\begin{array}{c}\cdot \\
+0,07 \\
\cdot \\
\cdot \\
\cdot\end{array}$ & $\begin{array}{l}\cdot \\
. \\
. \\
. \\
. \\
.\end{array}$ & $\begin{array}{c}\cdot \\
\cdot \\
+ \\
+0,29 \\
+0,09 \\
.\end{array}$ & $\begin{array}{r}\cdot \\
\cdot \\
- \\
\cdot \\
\cdot \\
-0,31\end{array}$ \\
\hline II & $\begin{array}{l}\text { Użytki techniczne } \\
\text { 1. Tereny przemysłowe: } \\
\text { a) bazy } \\
\text { b) magazyny } \\
\text { c) przemysł przetwórczy }\end{array}$ & $\begin{array}{l}72,69 \\
0,25 \\
0,18 \\
0,01 \\
0,06\end{array}$ & $\begin{array}{c}72,57 \\
0,16 \\
0,13 \\
0,03 \\
.\end{array}$ & $\begin{array}{l}. \\
. \\
. \\
.\end{array}$ & $\begin{array}{c}-0,12 \\
\cdot \\
\cdot \\
\cdot \\
\cdot\end{array}$ & $\begin{array}{l}. \\
. \\
. \\
.\end{array}$ & $\begin{array}{c}-0,09 \\
\cdot \\
\cdot \\
.\end{array}$ & $\begin{array}{c}\cdot \\
\cdot \\
+0,02 \\
\cdot\end{array}$ & $\begin{array}{c}\cdot \\
\cdot \\
-0,05 \\
\cdot \\
-0,06\end{array}$ \\
\hline & $\begin{array}{l}\text { 2. Tereny usługowe: } \\
\text { a) administracyjne } \\
\text { b) bankowe }\end{array}$ & $\begin{array}{l}24,2 \\
3,11 \\
0,54\end{array}$ & $\begin{array}{c}27,9 \\
2,7 \\
0,69\end{array}$ & $\begin{array}{l}. \\
.\end{array}$ & $\begin{array}{l}. \\
.\end{array}$ & $\begin{array}{c}+3,70 \\
\cdot \\
.\end{array}$ & $\begin{array}{l}. \\
.\end{array}$ & $\begin{array}{c}\cdot \\
+0,15\end{array}$ & $-0,41$ \\
\hline
\end{tabular}

${ }^{6}$ Jako 70. blok urbanistyczny przyjęto ulice i place. Dla czytelności obrazu nie uwzględniono go jednak na załączonych rysunkach. 
cd. tabeli 1

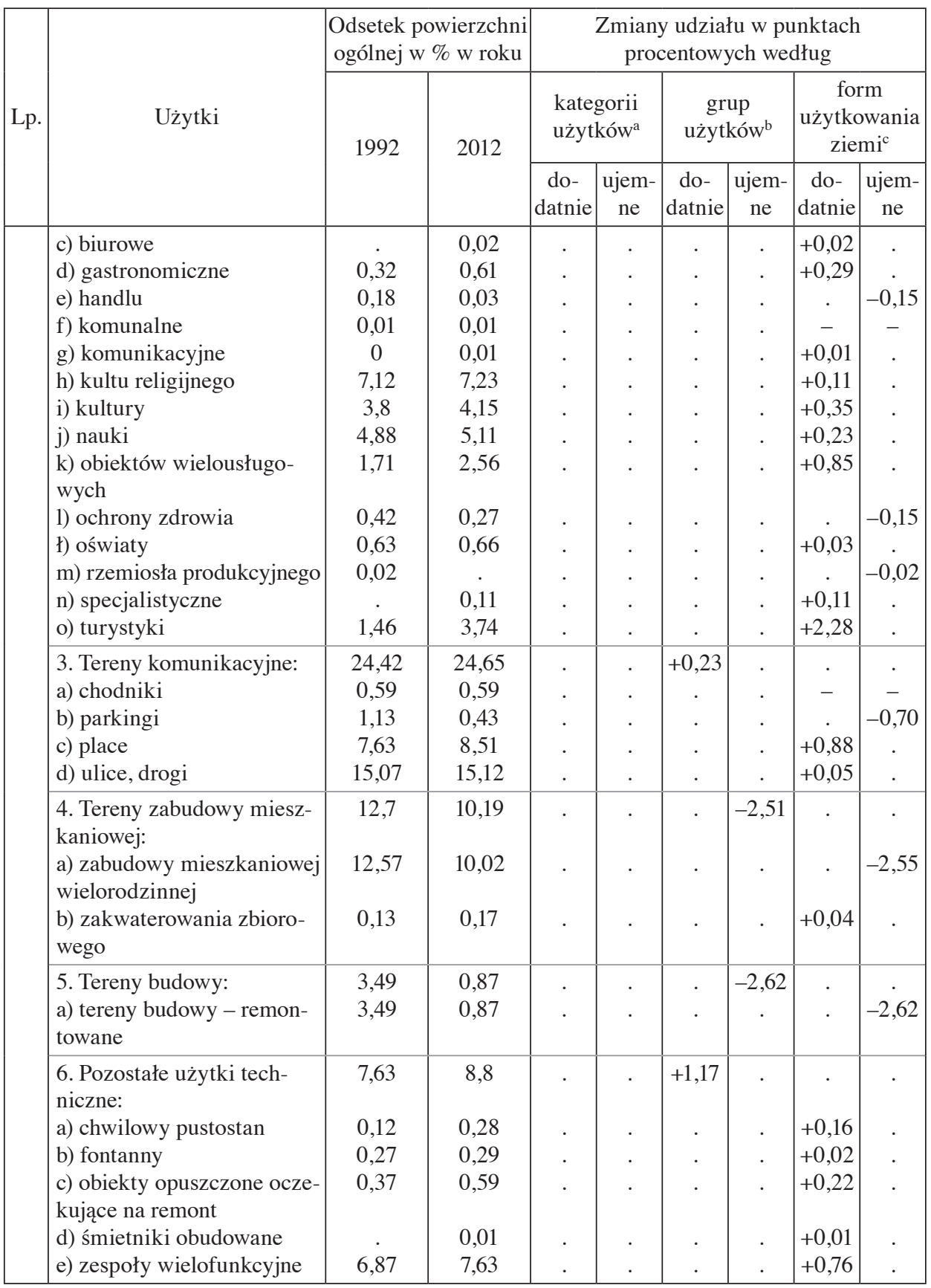


cd. tabeli 1

\begin{tabular}{|c|c|c|c|c|c|c|c|c|c|}
\hline \multirow{3}{*}{ Lp. } & \multirow{3}{*}{ Użytki } & \multicolumn{2}{|c|}{$\begin{array}{l}\text { Odsetek powierzchni } \\
\text { ogólnej w \% w roku }\end{array}$} & \multicolumn{6}{|c|}{$\begin{array}{l}\text { Zmiany udziału w punktach } \\
\text { procentowych według }\end{array}$} \\
\hline & & \multirow{2}{*}{1992} & \multirow{2}{*}{2012} & \multicolumn{2}{|c|}{$\begin{array}{l}\text { kategorii } \\
\text { użytków }\end{array}$} & \multicolumn{2}{|c|}{$\begin{array}{l}\text { grup } \\
\text { użytków }\end{array}$} & \multicolumn{2}{|c|}{$\begin{array}{c}\text { form } \\
\text { użytkowania } \\
\text { ziemic }^{c}\end{array}$} \\
\hline & & & & \begin{tabular}{|c|} 
do- \\
datnie
\end{tabular} & $\begin{array}{l}\text { ujem- } \\
\text { ne }\end{array}$ & $\begin{array}{c}\text { do- } \\
\text { datnie }\end{array}$ & $\begin{array}{c}\text { ujem- } \\
\text { ne }\end{array}$ & \begin{tabular}{|c|} 
do- \\
datnie
\end{tabular} & $\begin{array}{l}\text { ujem- } \\
\text { ne }\end{array}$ \\
\hline III & $\begin{array}{l}\text { Nieużytki } \\
\text { 1. Nieużytki sztuczne: } \\
\text { a) ruiny } \\
\text { b) pozostałe tereny zdegra- } \\
\text { dowane }\end{array}$ & $\begin{array}{l}0,11 \\
0,11 \\
0,09 \\
0,02\end{array}$ & $\begin{array}{l}0,16 \\
0,16 \\
0,16 \\
.\end{array}$ & $+0,05$ & . & $+0,05$ & . & $\begin{array}{c}\cdot \\
+0,07 \\
\cdot\end{array}$ & $-0,02$ \\
\hline & Śtem & 100 & 100 & $+0,12$ & $-0,12$ & $+5,22$ & $-5,22$ & $+7,04$ & $-7,04$ \\
\hline
\end{tabular}

Objaśnienia: - brak zmian, · brak zjawiska, ${ }^{\mathrm{a}} \mathrm{w}$ podziale użytków 1 . stopnia szczegółowości, ${ }^{\mathrm{b}} \mathrm{w}$ podziale użytków 2. stopnia szczegółowości, ${ }^{\mathrm{c}}$ w podziale użytków 3. stopnia szczegółowości.

Źródło: opracowanie własne na podstawie [Luchter 1994, s. 184].

W niniejszym artykule wykorzystane zostały ponadto inne prace autora [Luchter 1987a, 1990, 1997, 2010]. Uwzględniono także publikacje Z. Górki, w których szczegółowo przeanalizowana została była I dzielnica katastralna miasta Krakowa - Śródmieście. Podstawę stanowiły badania wykonane w skali 1 : 1000 [Górka 1974, 2004]. Posłużono się również pracą M. Nowakowskiej [1991], napisaną pod kierunkiem Z. Górki. Autorka na podstawie własnych badań terenowych dokonała w niej oceny przemian struktury użytkowania ziemi na terenie Śródmieścia Krakowa w latach 1970-1990.

Pomocne w analizie okazały się także opracowania innych autorów zajmujących się strukturą przestrzenną całego Krakowa, a w jego obrębie także Śródmieścia [Bromek 1966, Mydel 1979].

W pracy posłużono się również danymi zawartymi w opracowanym i uchwalonym miejscowym planie zagospodarowania przestrzennego obszaru Stare Miasto [Uchwała nr XII/131/11 w sprawie uchwalenia... 2011].

\section{Przemiany użytkowania ziemi w obrębie całej jednostki katastralnej}

Badania procesu przemian użytkowania ziemi przeprowadzone zostały dla całej jednostki katastralnej - Śródmieście. Zmiany w okresie ostatnich 20 lat w centralnej części miasta były niewielkie i potwierdzają opinię, że ta część Krakowa pod względem urbanistycznym została już wcześniej ukształtowana. 
Od prawie 30 lat (1983-2012) udział głównych kategorii użytków kształtował się na podobnym poziomie (np. w 1983 r. udział użytków technicznych ${ }^{7}$ wyniósł 71,85\%, w 1992 r. - 72,7\%, w 2012 r. - 72,6\%, a terenów zielonych odpowiednio: $28,15 \%, 27,2 \%$ i $27,3 \%$ [Luchter 1994, s. 186] - por. tabela 1).

Niepokojącym procesem jest pojawienie się w latach 1983-2012 w tej części miasta nieużytków. W 1983 r. w trakcie badań autora prowadzonych w ramach pracy doktorskiej tego typu użytków nie zarejestrowano. W 1992 r. ich udział wyniósł 0,11\%, a w 2012 r. - 0,16\%. Były to głównie ruiny budynków - przeważnie niegdyś mieszkalnych, których z różnych powodów nie zaczęto w analizowanym okresie remontować. Klasycznym przykładem może być tutaj obiekt przy ul. Grodzkiej 59 (blok urbanistyczny nr 64 - por. rys. 1), który w 1992 r. zakwalifikowany został do tzw. obiektów opuszczonych oczekujących na remont ${ }^{8}$, a po 20 latach, wskutek braku jakichkolwiek przejawów działań zmierzających do jego wyremontowania i odnowy, autor zdecydował się całą tę działkę ewidencyjną 9 zakwalifikować do nieużytków sztucznych - ruin.

$\mathrm{W}$ przypadku terenów zielonych ${ }^{10}$ zmiany w ostatnich 20 latach były niewielkie i wiązały się m.in. z likwidacją zieleńca (na terenie bloku nr 10 - por. rys. 1) i postawieniem na jego miejscu dwóch hoteli. Dla odmiany w innej części tej dzielnicy (blok urbanistyczny $\mathrm{nr} 53$ - por. rys. 1) doszło do nieznacznego wzrostu powierzchni innych terenów zielonych - parków, wskutek oddania do użytku tzw. ogrodu profesorskiego przy ul. Jagiellońskiej.

O wiele większe zmiany zarejestrowane zostały w obrębie użytków technicznych, których udział w powierzchni ogólnej Śródmieścia utrzymywał się na poziomie $72-73 \%{ }^{11}$ (w 1848 r. - ok. 74\% [Luchter 1987b, tab. 1], co oznaczało, że od blisko 165 lat struktura użytkowania ziemi w tej części Krakowa niewiele się zmieniła).

${ }^{7}$ Nomenklatura została wprowadzona do literatury przez K. Bromka [1966, s. 9].

${ }^{8}$ Charakterystyka tego typu obiektów została zaprezentowana w pracy habilitacyjnej autora [Luchter 2010, s. 40].

${ }^{9}$ Działka ewidencyjna, zgodnie z najnowszym rozporządzeniem w sprawie ewidencji gruntów, to „ciągły obszar gruntu, położony w granicach jednego obrębu, jednorodny pod względem prawnym, wydzielony z otoczenia za pomocą linii granicznych" [Rozporządzenie... 2001, s. 2779]. Działki ewidencyjne wchodzą też w skład bloków urbanistycznych [Górka 2004, s. 9].

${ }^{10}$ Nazwa ,tereny zielone” została przyjęta przez autora w ostatnich pracach, w tym w pracy habilitacyjnej. Pierwotnie, zgodnie z klasyfikacją przyjętą przez K. Bromka i R. Mydela [1972], autor posługiwał się nomenklaturą ,użytki zielone” (które obejmowały zarówno użytki rolne, leśne, jak i pozostałą - tj. nierolniczą i nieleśną, zieleń). Dla odróżnienia jednak od używanej w ewidencji gruntów nazwy „użytki zielone” (oznaczającej łąki i pastwiska), autor zdecydował się posługiwać nazwą ,tereny zielone”.

${ }^{11}$ Potwierdziły to także badania Z. Górki. W 1970 r. udział użytków technicznych w Śródmieściu wyniósł 72,1\%, a w 1980 r. - 73,1\% [Górka 2004, s. 32, tab. 4]. 
Przede wszystkim, w obrębie głównych grup użytków zarejestrowano ubytek powierzchni terenów przemysłowych, terenów budowy, terenów zabudowy mieszkaniowej, a wzrost powierzchni terenów usługowych, terenów komunikacyjnych i pozostałych użytków technicznych. Ubytek powierzchni terenów przemysłowych wiązał się ze spadkiem powierzchni terenów przemysłu przetwórczego (w $2009 \mathrm{r}$. zamknięto Drukarnię Związkową przy ul. Mikołajskiej) i ostatecznie całkowitym zanikiem tych użytków (por. tabela 1).

W przypadku terenów usługowych, przy ogólnej tendencji wzrostowej ich powierzchni, zanotowano spadek powierzchni terenów: administracji, handlu, ochrony zdrowia, rzemiosła produkcyjnego ${ }^{12}$, natomiast wzrost powierzchni pozostałych użytków, największy (powyżej 0,25 punktu procentowego) terenów: turystyki, obiektów wielousługowych, kultury, gastronomii i nauki. Na uwagę zasługuje prawie 2,6-krotny wzrost powierzchni terenów turystyki, wiążący się z powstawaniem hosteli, apartamentów, a także nowych hoteli, niekiedy wybudowanych od podstaw (np. Campanile, Classic).

Przyrost powierzchni terenów nauki, kultury, turystyki czy gastronomii świadczy o umacnianiu się podstawowych funkcji Krakowa, wyróżnianych w planach zagospodarowania przestrzennego zarówno przed II wojną światową, jak i tuż po jej zakończeniu [Luchter 2007].

Nieznaczny przyrost powierzchni terenów komunikacyjnych wiązał się m.in. z likwidacją bazy budowlanej na placu św. Marii Magdaleny.

W obrębie tzw. pozostałych użytków technicznych nastąpił przyrost powierzchni wszystkich form użytkowania ziemi, największy w obrębie zespołów wielofunkcyjnych (o 0,76 punktu procentowego), obiektów opuszczonych oczekujących na remont i chwilowego pustostanu.

Badania w obrębie kategorii, grup i form użytkowania ziemi pozwoliły na wysunięcie wniosków: im większa jest szczegółowość klasyfikacji użytków, tym większe są wahania wskaźnika $\left|z_{i}\right|$, im mniejsza jest ona - tym mniejsze są wahania tego wskaźnika. Wartość $\left|z_{i}\right|$ wyliczona dla zmienności procentowego udziału powierzchni poszczególnych kategorii użytków - wyniosła zaledwie 0,12, grup $-5,22$, a form $-7,04$ (por. tabela 1).

\section{Przemiany użytkowania ziemi według bloków urbanistycznych}

Oprócz przemian użytkowania ziemi prześledzonych dla ogólnej powierzchni byłej I dzielnicy katastralnej miasta Krakowa - Śródmieście, dokonano analizy

${ }^{12} \mathrm{~W}$ przypadku terenów rzemiosła produkcyjnego zarejestrowano nawet zanik tego typu użytków w minionym okresie. 
w oparciu o jednostki przestrzenne, ograniczone najczęściej ulicami bądź innymi liniami rozgraniczającymi, tj. bloki urbanistyczne.

Na terenie tej części miasta wyróżniono 69 bloków urbanistycznych. Dokonano także oceny - na obszarze dróg i ulic, które zajmowały w 2012 r. ok. 1/4 powierzchni analizowanej dzielnicy (28\% w $1848 \mathrm{r}$. [Luchter 1987b, tabela 1]) i tworzyły swoisty -70 . blok urbanistyczny, ograniczony ulicami przebiegającymi wokół Śródmieścia, stanowiącymi I obwodnicę miasta (por. rys. 1).

Badania przeprowadzono osobno dla kategorii użytków (w podziale użytków pierwszego stopnia szczegółowości podziału użytków), grup użytków (w podziale drugiego stopnia) i form użytkowania ziemi (w podziale trzeciego stopnia).

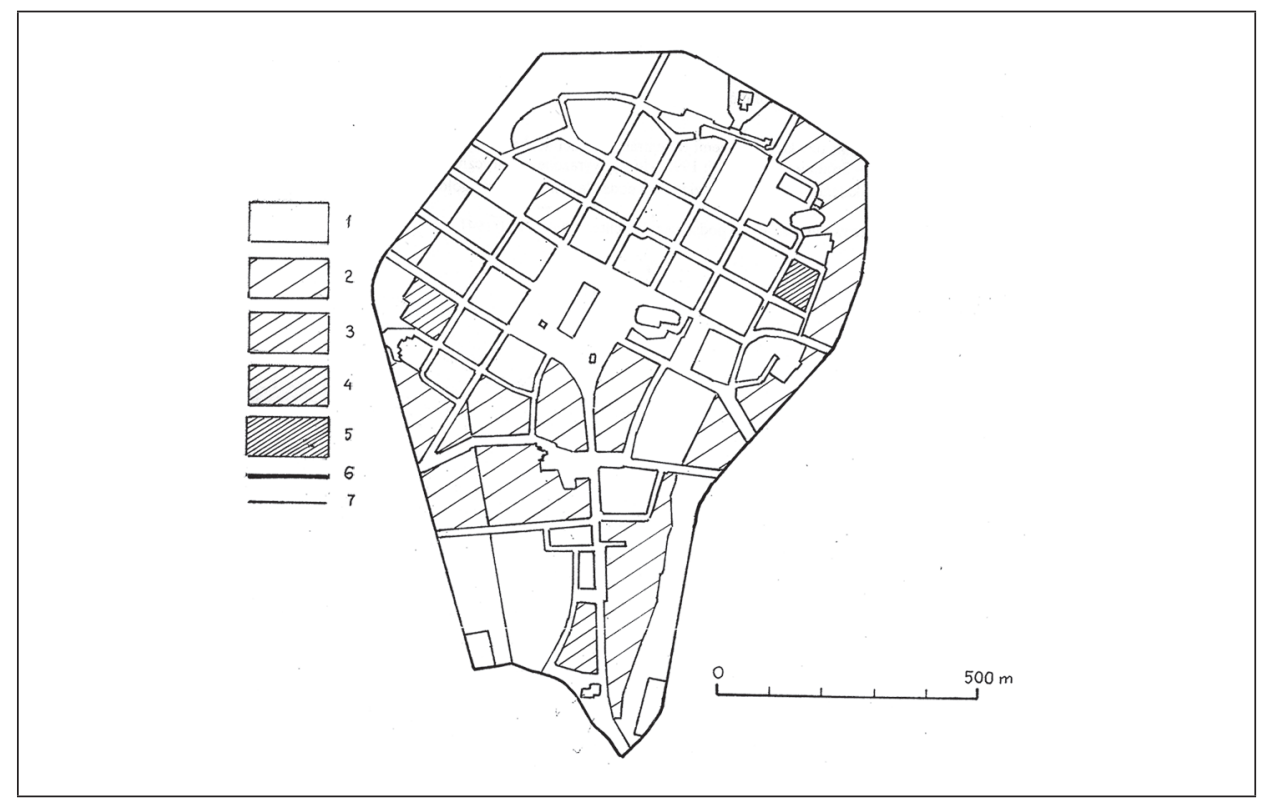

Objaśnienia: 1 - brak zmian, $z_{i}=0,2-0<\left|z_{i}\right| \leq 5,3-5<\left|z_{i}\right| \leq 10,4-10<\left|z_{i}\right| \leq 25,5-$ $25<\left|z_{i}\right| \leq 50,6$ - granice byłej I dzielnicy katastralnej miasta Krakowa - Śódmieście, 7 - granice bloków urbanistycznych.

Rys. 2. Zmiany użytkowania ziemi w centralnej części Krakowa byłej I dzielnicy katastralnej - Śródmieście w latach 1992-2012, wyrażone sumarycznymi wartościami $\left|z_{i}\right|$ - według kategorii użytkowania ziemi (w podziale pierwszego stopnia szczegółowości użytków)

Źródło: opracowanie własne na podstawie [Luchter 1994, s. 181-194].

Im więcej użytków zostało wyróżnionych, tym większe odnotowano wahania wartości $\left|z_{i}\right|$. Na przykład w podziale użytków pierwszego stopnia szczegółowości 
podziału wartość $z_{i}=0$ aż dla 54 bloków urbanistycznych (78\% ogółu bloków), przy średniej dla Śródmieścia $\left|z_{i}\right|=0,12$.

Maksymalna wartość $\left|z_{i}\right|$, wahająca się w przedziale (25-50) odnotowana została tylko dla jednego bloku urbanistycznego - tj. nr 10, na którego obszarze w miejsce terenów zielonych pojawiły się użytki techniczne (rys. 2).

W podziale drugiego stopnia - na tzw. grupy użytków, wartość $z_{i}$ była już wyższa niż dla kategorii i wyniosła dla ogółu dzielnicy 5,22. Dla 20 bloków urbanistycznych (ok. 29\%) $z_{i}=0$ (por. rys. 3). W przypadku trzech bloków urbanistycznych $(9,34,63)$ wartość $50<\left|z_{i}\right| 100$, przy czym dla bloku nr 34 (blok złożony z pojedynczego obiektu, jakim są Sukiennice) wyniosła maksymalnie 100. W 1992 r. ta forma użytkowania ziemi była częściowo w remoncie, stąd zakwalifikowana została do tzw. użytków technicznych - pozostałych, natomiast w 2012 r. - do terenów usługowych.

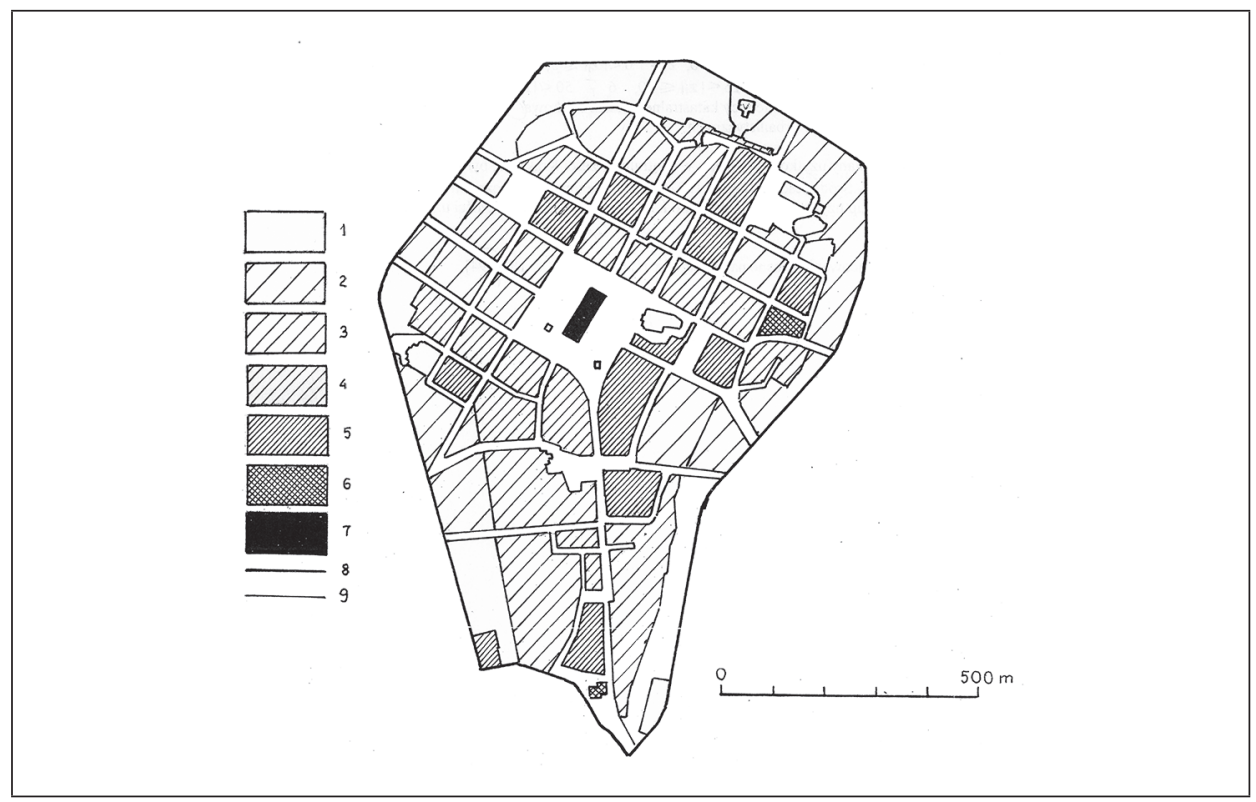

Objaśnienia: 1 - brak zmian, $z_{i}=0,2-0<\left|z_{i}\right| \leq 5,3-5<\left|z_{i}\right| \leq 10,4-10<\left|z_{i}\right| \leq 25,5-$ $25<\left|z_{i}\right| \leq 50,6-50<\left|z_{i}\right| \leq 75,7-75<\left|z_{i}\right| \leq 100,8$ - granice byłej I dzielnicy katastralnej miasta Krakowa - Śródmieście, 9 - granice bloków urbanistycznych.

Rys. 3. Zmiany użytkowania ziemi w centralnej części Krakowa byłej I dzielnicy katastralnej - Śródmieście w latach 1992-2012, wyrażone sumarycznymi wartościami $\left|z_{i}\right|$ według grup użytkowania ziemi (w podziale drugiego stopnia szczegółowości użytków)

Źródło: opracowanie własne na podstawie [Luchter 1994, s. 181-194]. 
Podział na formy użytkowania ziemi (zgodnie z trzecim stopniem szczegółowości podziału) pozwolił na obserwację jeszcze większych zmian. Łączna dla Śródmieścia wartość $\left|z_{i}\right|=7,04$ (por. tabela 1) była wyższa niż w podziale drugiego, a także pierwszego stopnia szczegółowości na grupy i kategorie użytków. Potwierdziło to zależność pomiędzy wzrostem stopnia szczegółowości użytków a wzrostem natężenia zmian zachodzących w strukturze użytkowania ziemi. Już tylko dla 19 bloków urbanistycznych wartość $\left|z_{i}\right|=0$ (rys. 4). W dziewięciu przypadkach brak zmian zarejestrowano w obrębie bloków urbanistycznych złożonych wyłącznie z jednego obiektu, niezmieniającego swojego charakteru użytkowania od co najmniej 20 lat. Dotyczyło to: Barbakanu (nr 2) ${ }^{13}$, kościoła św. Krzyża (nr 14), teatru Miniatura (nr 15), teatru im. J. Słowackiego (nr 16), kościoła NMP (nr 33), kościoła św. Wojciecha (nr 39), Wieży Ratuszowej (nr 42), Collegium Novum (nr 54) ${ }^{14}$ i hotelu Royal (nr 62). W ośmiu przypadkach brak zmian zarejestrowano w obrębie bloków urbanistycznych stanowiących Planty (nr 1, 3, 25, 27, 49, 52, 61, 68), a w dwóch - dla złożonych z dwóch kategorii użytków, dwóch grup użytków i dwóch form użytkowania ziemi - bloków urbanistycznych (nr 26 i 28). Bloki te zajmowały w większości skrajne położenie w stosunku do Rynku Głównego, stanowiącego do chwili obecnej centrum historyczne, kulturowe i ekonomiczne Krakowa.

Największe zmiany (powyżej 25 punktów procentowych, a zasadniczo procent, gdyż powierzchnia porównawcza w latach 1992-2012 nie uległa zmianie), zarejestrowane zostały na terenie 20 bloków urbanistycznych (wobec 15 - w podziale na grupy użytków, czy jednego - w podziale na kategorie). W przypadku podziału na formy użytkowania ziemi wartość $z_{i}$ wahała się w przedziale (50-100] dla czterech bloków urbanistycznych (nr 9, 18, 34, 63). Maksymalnie $\left(\left|z_{i}\right|=100\right)$ osiągnęła - podobnie jak w podziale drugiego stopnia szczegółowości na grupy użytków - tylko dla jednego z nich - tj. nr 34, złożonego wyłącznie z Sukiennic. W 1992 r. zaliczone one zostały, zgodnie z trzecim stopniem podziału użytków, do zespołów wielofunkcyjnych (wyróżnionych w obrębie użytków technicznych pozostałych), a w 2012 r., także w podziale trzeciego stopnia szczegółowości - na formy, do obiektów wielousługowych (w ramach terenów usługowych - wyodrębnionych z użytków technicznych), o czym zadecydowały różnego rodzaju pomieszczenia usługowe przeznaczone na 1. kondygnacji na działalność handlową (pięć sklepów - znajdujących się na zewnątrz i 54 stoiska z pamiątkami - zlokalizowane wewnątrz, $\mathrm{tj}$. w hallu budynku), gastronomiczną (m.in. cukiernię i restaurację Noworolski), kulturową (Muzeum Historyczne Miasta Krakowa - Podziemia

${ }^{13} \mathrm{~W}$ nawiasie podano numer bloku urbanistycznego (por. rys. 1).

${ }^{14} \mathrm{~W}$ październiku 2013 r. obiekt ten znajdował się w remoncie. Po jego zakończeniu - w maju 2014 r. z racji obchodów 650-lecia Uniwersytetu Jagiellońskiego ponownie przywrócona została mu funkcja nauki [Stachnik 2014, s. B5]. 
Rynku $\left.{ }^{15}\right)$, natomiast na 2. kondygnacji - gastronomiczną (Cafe „Szał”) i kulturową (Oddział Muzeum Narodowego). Ponadto w podziemiach (-1. kondygnacja) usytuowano usługi komunalne (WC).

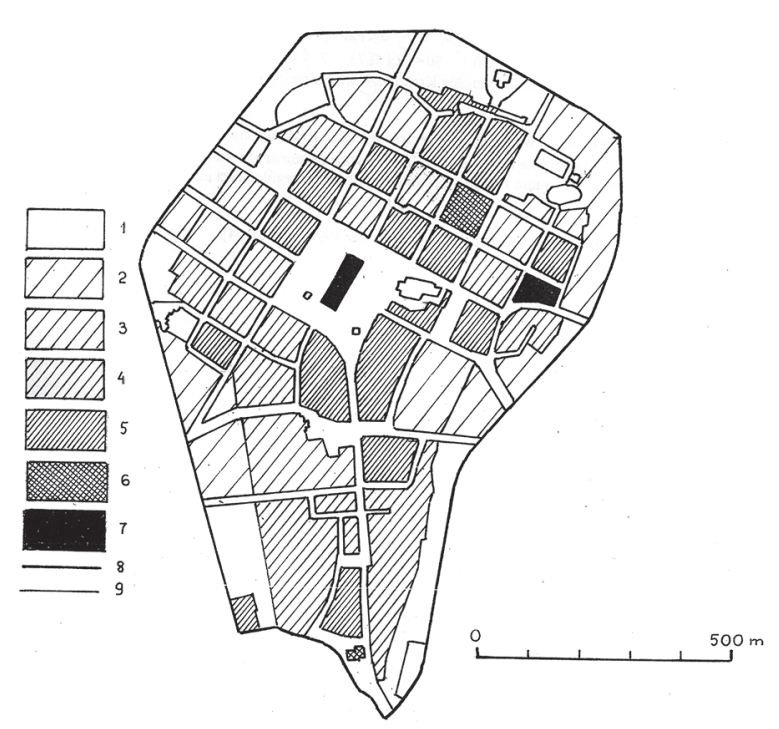

Objaśnienia: 1 - brak zmian, $z_{i}=0,2-0<\left|z_{i}\right| \leq 5,3-5<\left|z_{i}\right| \leq 10,4-10<\left|z_{i}\right| \leq 25,5-$ $25<\left|z_{i}\right| \leq 50,6-50<\left|z_{i}\right| \leq 75,7-75<\left|z_{i}\right| \leq 100,8-$ granice b. dzielnicy katastralnej miasta Krakowa-Śródmieście, 9 - granice bloków urbanistycznych.

Rys. 4. Zmiany użytkowania ziemi w centralnej części Krakowa, byłej I dzielnicy katastralnej - Śródmieście w latach 1992-2012, wyrażone sumarycznymi wartościami $\left|z_{i}\right|$ - według form użytkowania ziemi (w podziale trzeciego stopnia szczegółowości użytków)

Źródło: opracowanie własne na podstawie [Luchter 1994, s. 181-194].

Bardzo duże przeobrażenia strukturalne zaobserwowane zostały na terenie bloku nr 9. W obrębie kategorii użytków nie zarejestrowano tu wprawdzie żadnych zmian $\left(z_{i}=0\right)^{16}$, natomiast już w podziale na grupy wartość $\left|z_{i}\right|$ znalazła się w przedziale (50-75]. W obrębie użytków technicznych nastąpił przyrost

${ }^{15}$ W większości muzeum to, oddane do użytku 24 września 2010 r. [Suchy i Hajok 2010, s. 1], mieściło się pod Sukiennicami, a zwłaszcza płytą Rynku Głównego. Na parterze (1. kondygnacja) znajdowały się: Informacja, Rezerwacja, Sprzedaż Biletów oraz wejście do tego obiektu.

${ }^{16}$ Zarówno w 1992 r., jak i w 2012 r. 100\% powierzchni tego bloku urbanistycznego stanowiły użytki techniczne. 
powierzchni terenów usługowych i zabudowy mieszkaniowej, a ubytek - terenów budowy i użytków technicznych pozostałych. Podział trzeciego stopnia szczegółowości - na formy użytkowania ziemi, pozwolił stwierdzić na obszarze tego bloku urbanistycznego zmiany powierzchni w obrębie głównie terenów usługowych, co zaważyło na wartości $\left|z_{i}\right|=85,66$. W latach 1992-2012 nastąpił ubytek i ostatecznie zanik powierzchni terenów bankowych (w budynku przy ul. św. Tomasza 43/Mikołajska 32, w miejsce mieszczącego się tu w 1992 r. Banku Przemysłowo-Handlowego ${ }^{17}$ funkcjonowała w 2012 r. Akademia Muzyczna), a wzrost powierzchni terenów nauki i turystyki (w znajdujących się w 1992 r. w remoncie obiektach, w 2012 r. - mieściły się nowo powstałe hotele: Amadeus przy ul. św. Krzyża 9/Mikołajska 22/20, oraz Wit Stwosz przy ul. Mikołajskiej 28 i aparthotel Mikołaj - przy ul. Mikołajskiej 30).

\section{Uwagi końcowe}

Przeprowadzone badania zarówno dla całej jednostki przestrzennej byłej I dzielnicy katastralnej miasta Krakowa - Sródmieście, jak i w podziale na bloki urbanistyczne wykazały istotne zmiany jakościowe, o czym świadczyły zróżnicowania wartości $z_{i}$ w podziale na kategorie, grupy i formy użytkowania ziemi.

Można jednoznacznie stwierdzić, że im więcej użytków przyjętych zostało do analizy, tym bardziej wartość $\left|z_{i}\right|$ wzrastała. Wzrost wartości $\left|z_{i}\right|$ zaobserwowany został również wówczas, gdy przyjęto podział na bloki urbanistyczne. A więc im bardziej szczegółowo zostały przeprowadzone badania, tym wyższe były sumaryczne wartości odchyleń procentowego udziału użytków. Na przykład dla całej jednostki katastralnej Śródmieście w podziale na kategorie użytków (wyróżnione zgodnie z pierwszym stopniem szczegółowości użytków) wartość $\left|z_{i}\right|$ wyniosła zaledwie 0,12 , podczas gdy w podziale na grupy użytkowania ziemi (według drugiego stopnia szczegółowości użytków) czy formy użytkowania ziemi (wyodrębnionych według trzeciego stopnia szczegółowości użytków) oraz bloki urbanistyczne - wartość $\left|z_{i}\right|$ osiągnęła maksymalne rozpiętości [0-100].

Badania potwierdziły procesy świadczące o dalszym utrwalaniu się głównych funkcji Krakowa - kultury, nauki i turystyki, przejawiające się wzrostem powierzchni terenów użytkowanych przez tego typu usługi. Realizacja zasad gospodarki rynkowej przyczyniła się także do wzrostu powierzchni (niekiedy w znaczącym stopniu) terenów bankowych, biurowych, gastronomicznych, a także innych użytków charakterystycznych dla centralnych części miast,

${ }^{17}$ W 1983 r. w budynku tym mieścił się Komitet Wojewódzki Polskiej Zjednoczonej Partii Robotniczej. 
tj. obiektów chwilowego pustostanu, zespołów wielofunkcyjnych czy obiektów wielousługowych.

Zaobserwowano natomiast spadek powierzchni terenów zajętych przez usługi: administrację, handel, ochronę zdrowia, oświatę, a także zabudowę mieszkaniową - co świadczyło o dalszym wyludnianiu się Śródmieścia Krakowa, czy przemysł.

Tego typu przemiany wskazywały na zaawansowane procesy metropolizacyjne, odznaczające się wzrostem powierzchni terenów przeznaczonych pod realizację funkcji usługowych najwyższego rzędu, zaliczanych przez T. Markowskiego i T. Marszała [2006, s. 13] do sektora IV (m.in. naukowych, kulturalnych, turystycznych, finansowych, informacyjnych), a spadkiem powierzchni terenów przeznaczonych do realizacji funkcji podstawowych (np. ochrony zdrowia czy oświaty).

\section{Literatura}

Bromek K. [1966], Użytkowanie ziemi w Krakowie i przyległych częściach powiatu krakowskiego około 1960 roku, Zeszyty Naukowe UJ, nr 128, Kraków.

Bromek K., Mydel R. [1972], Uwagi metodyczne do opracowania szczegółowej mapy u̇zytkowania ziemi przestrzeni miejskiej, Folia Geographica, Series Geographica-Oeconomica, t. 5.

Górka Z. [1974], Użytkowanie ziemi w I dzielnicy katastralnej miasta Krakowa - Śródmieście, Zeszyty Naukowe UJ, nr 379, Kraków.

Górka Z. [2004], Krakowska dzielnica staromiejska w dobie społeczno-ekonomicznych przemian Polski na przełomie XX i XXI wieku, Instytut Geografii i Gospodarki Przestrzennej UJ, Kraków.

Grocholska [1974], Czynniki wpływajace na użytkowanie ziemi w Warszawie, Studia KPZK PAN, t. 46.

Kraków się powiększyt [2013], „Krakowski Rynek Nieruchomości”, nr 1.

Luchter B. [1987a], Kierunki przemian użytkowania ziemi w aglomeracji krakowskiej, Akademia Ekonomiczna w Krakowie, Praca doktorska, Maszynopis.

Luchter B. [1987b], Użytkowanie ziemi w Krakowie w świetle planu katastralnego z I poł. XIX w., ,Zeszyty Naukowe AE w Krakowie”, nr 251.

Luchter B. [1990], Przestrzenne zwiazki użytkowania ziemi w Krakowie, „Dokumentacja Geograficzna", z. 2-3.

Luchter B. [1994], Zmiany użytkowania ziemi w Krakowie w latach 1983-1992 na przykładzie centralnej czę́si miasta - byłej I dzielnicy katastralnej - Śródmieście, „Zeszyty Naukowe AE w Krakowie”, nr 422.

Luchter B. [1997], Zmiany w zagospodarowaniu centralnej częśsi Krakowa, w okresie transformacji (ze szczególnym uwzględnieniem lat 1992-1995), „Zeszyty Naukowe AE w Krakowie", $\mathrm{nr} 483$.

Luchter B. [2007], Wpływ planowania przestrzennego na strukture użytkowania ziemi w Krakowie [w:] Księga jubileuszowa dla uczczenia 80. rocznicy urodzin Profesora Antoniego Fajferka, AE w Krakowie, Kraków.

Luchter B. [2010], Przemiany w użytkowaniu ziemi w rozwoju miasta Krakowa, Zeszyty Naukowe UEK w Krakowie, Seria specjalna: Monografie, nr 196, Kraków. 
Markowski T., Marszał T. [2006], Metropolie, obszary metropolitalne, metropolizacja: problemy i pojęcia podstawowe, PAN, KPZK, Warszawa.

Mydel R. [1979], Rozwój struktury przestrzennej miasta Krakowa, Ossolineum, Wrocław. Nowakowska M. [1991], Zmiany użytkowania ziemi w dzielnicy Śródmieście w Krakowie w obrębie Plant w okresie 1970-1990, Instytut Geografii UJ, Kraków, Praca magisterska, maszynopis.

Rozporządzenie Ministra Rozwoju Regionalnego i Budownictwa z 29 marca 2001 r., w sprawie ewidencji gruntów i budynków [2001], Dz.U. nr 38 z 2 maja 2001 r., poz. 454.

Stachnik P. [2014], Kłótnie i sprzeczne koncepcje. Tak powstało Collegium Novum, „Dziennik Polski”, nr 107(21246).

Suchy B., Hajok D. [2010], Zabiło podziemne serce, „Gazeta Wyborcza. Dodatek Kraków", nr 225(7043).

Uchwała nr XII/131/11 w sprawie uchwalenia miejscowego planu zagospodarowania przestrzennego obszaru Stare Miasto [2011], Dz.Urz. Woj. Małopolskiego nr 255 z 17 maja 2011, poz. 2059.

\section{Changes in Land Use in Cracow's City Centre, 1992-2012}

The aim of this article is to evaluate land use changes taking place under the influence of the processes resulting from the implementation of market economy principles in the years 1992-2012 in Central Cracow. The research covered both the entire central district and the urban blocks that belong to that area. For greater inference accuracy, the analysis was conducted according to land use categories (the first grade accuracy of land use division) as well as the groups (the second grade division) together with the forms of land use (the third grade division). The research revealed an increase in metropolitan processes manifested by growth in the actual service area devoted in the city to culture, education and tourism, which have a particularly international reach. These three areas have for many years played a leading role in Cracow's spatial and socio-economic development.

Keywords: economic geography, settlement geography, spatial economy, land use in urban space. 